\title{
Mullins Effect and Crack Growth in Natural Rubber Vulcanizates during Heat Aging and Cyclic Loading
}

\author{
Hiệu ứng Mullins và quá trình phát triển vết nứt của hỗn hợp cao su thiên nhiên
} trong lão hóa nhiệt và tải trọng chu kỳ

\author{
Nguyen Trong Quang ${ }^{1,2}$, Dang Viet Hung ${ }^{1 *}$, Bui Chuong ${ }^{1}$, Tran Trung Le ${ }^{1}$ \\ ${ }^{1}$ Center for Polymer Composite and Paper, Hanoi University of Science and Technology, Hanoi, Vietnam \\ ${ }^{2}$ Hung Yen University of Technology and Education, Hung Yen, Vietnam \\ *Email: hung.dangviet@hust.edu.vn
}

\begin{abstract}
The effect of thermal aging and cyclic loading on mechanical properties and development of cracks in natural rubber vulcanizates was studied. After aging at $70^{\circ} \mathrm{C}$ and $110^{\circ} \mathrm{C}$ vulcanizates were subjected to cyclic loading. At a certain number of loading cycles, the samples were conducted in a tension test. At the aging condition of $70{ }^{\circ} \mathrm{C}$, the static tensile properties of material stay almost unchanged even after 88 aged hours and 8000 loading cycles. On the contrary, the dynamic fatigue resistance of vulcanizates decreases with increasing aging time. These results are attributed to the post-curing and the development of microcracks that might be caused by Mullins effect: in the case of static loading, the strain-induced crystallization may prevent cracks growth, but in the case of cyclic loading the strain-induced crystallization does not occur, so cracks develop without hindrance. However, at $110^{\circ} \mathrm{C}$ both static properties and dynamic fatigue resistance of material reduced dramatically because at high temperature the heat degradation exceeds both post-curing and straininduced crystallization. Crack formation and propagation were examined by a digital optical microscope in the progress of cyclic loading. Results showed that natural rubber vulcanizate filled with carbon black has the best crack growth resistance (CGR) while the addition of modified and unmodified silica reduces CGR of materials. Moreover, the vulcanizate with unmodified silica has the lowest CGR.
\end{abstract}

Keywords: Natural rubber, silica modified and unmodified, crack growth, cyclic loading, Mullins effect.

Tóm tắt

Ảnh hưởng của lão hóa nhiệt và tải trọng theo chu kỳ lên các tính chất cơ học và sự phát triển của các vết nứt trong cao su tự nhiên đã được nghiên cứu. Sau khi lão hóa ở $70^{\circ} \mathrm{C}$ và $110^{\circ} \mathrm{C}$ cao su tiếp tục chịu tải theo chu kỳ. Ở điều kiện lão hóa $70^{\circ} \mathrm{C}$, độ bền kéo đứt của vật liệu gần như không thay đổi ngay cả sau 88 giờ và 8000 chu kỳ. Ngược lại, khả năng chịu mỏi động của cao su giảm đi khi thời gian lão hóa tăng lên. Những kết quả này được cho là do hiện tượng cao su tiếp tục được lưu hóa (còn gọi là hậu lưu hóa) và sự phát triển của các vết nứt vi mô có thể gây ra bởi hiệu ứng Mullins: trong trường hợp tải tĩnh, sự kết tinh do biến dạng có thể ngăn chặn sụ̣ phát triển vết nứt, nhưng trong trường hợp tải theo chu kỳ sụ̂ kết tinh đó không xảy ra, vì vậy các vết nứt phát triển mà không gặp trở ngại. Tuy nhiên, ở $110^{\circ} \mathrm{C}$ cả tính chất tĩnh và khả năng chống mỏi động của vật liệu suy giảm nghiêm trọng, vì hiện tượng hậu lưu hóa và kết tinh do biến dạng không thể bù lại được với sự phá hủy rất lớn của cao su khi ở nhiệt độ cao. Sự hình thành và lan truyền vết nứt đã được kiểm tra bằng kính hiển vi quang học kỹ thuật số trong quá trình tải trọng động theo chu kỳ. Kết quả cho thấy cao su thiên nhiên chứa chất độn than có khả năng chống sự phát triển vết nứt (CGR) tốt nhất, trong khi việc bổ sung silica biến tính và không biến tính làm giảm CGR của vật liệu. Hơn nữa, cao su thiên nhiên với silica không biến tính có CGR thấp nhất.

Từ khóa: Cao su thiên nhiên, silica, silica biến tính, phát triển vết nứt, tải trọng chu kỳ, hiệu ứng Mullins

\section{Introduction}

Natural rubber (NR) is a material that has wide application in rubber products working in the condition of dynamic loading due to its high dynamic properties [1]. However, its disadvantage is low heat aging resistance, both in static and cyclic loading [1]. This disadvantage is shown more clearly in the case of

ISSN: $2734-9381$

https://doi.org/10.51316/jst.153.etsd.2021.31.4.11

Received: August 23, 2019; accepted: August 10, 2020 cyclic loading because NR was characterized by high heat generation from hysteresis loss.

Using reinforcing filler, such as carbon black (CB) or silica, enhances the mechanical properties of rubber $[1,2]$. The stress softening effect can occur when NR is subjected to a cyclic loading $[3,4]$. The presence of nanofillers in rubbers may lead to more complex structural changes that take place under the 
Mullins effect, which has direct effect on properties of filled rubbers. In this article, the influence of the Mullins effect on NR properties during heat aging and cyclic loading is studied. In addition, the relation between fillers such as $\mathrm{CB}$ and silica and crack growth in NR is also investigated.

\section{Experiment}

\subsection{Materials}

Natural rubber: Ribbed smoked sheet (RSS), Mooney viscosity $\mathrm{ML}(1+4) 100=92$, the density of $0.9 \mathrm{~g} / \mathrm{cm} 3$, from Vietnam; Unmodified silica: $\mathrm{SiO}_{2}$ Utrasil VN3, 99\% purity, was supplied by Evonik; Modified silica: $\mathrm{SiO}_{2}$ was modified by Bis(triethoxysilylpropyl) tetrasulfide silane (TESPT), 99\% purity as in our previous work [5]; Carbon black: N330, the particle size of 24 - $32 \mathrm{~nm}$, was supplied by Shanxi Lixin Chemical Co., Ltd, China; CPC Processing oil (paraffinic base), Viscosity Index $(V I)=97$, was supplied by CPC Corporation, Taiwan. Additives: Antidegradant 2,2,4-trimethyl-1,2dihydroquinone (RD); Antidegradant N-1,3dimethylbutyl-N'-phenyl-p-phenylenediamine (4020), Stearic acid; Accelerators Tetramethyl thiuram disulfide (TMTD), Accelerators N-tbutylbenzothiazole-2-sulfenamide (TBBS), zinc oxide $(\mathrm{ZnO})$, Sulphur (S). All chemicals are technical grades from China. Rubber mixtures were prepared according to Table 1 as in our previous article [6].

Table 1. NR formulations

\begin{tabular}{|l|c|c|c|}
\hline Ingredients & $\mathrm{NR} / \mathrm{CB}$ & $\begin{array}{c}\mathrm{NR} / \mathrm{CB} / \\
\mathrm{SiKBT}\end{array}$ & $\begin{array}{c}\mathrm{NR} / \mathrm{CB} / \\
\mathrm{SiBT}\end{array}$ \\
\hline Natural rubber RSS & 100 & 100 & 100 \\
\hline Antidegradant RD & 1.5 & 1.5 & 1.5 \\
\hline Antidegradant 4020 & 1.5 & 1.5 & 1.5 \\
\hline Carbon black N330 & 33.0 & 33.0 & 33.0 \\
\hline ZnO & 5.0 & 5.0 & 5.0 \\
\hline Stearic acid & 2.0 & 2.0 & 2.0 \\
\hline CPC oil & 1.5 & 1.5 & 1.5 \\
\hline SiO 2, Unmodified & 0 & 3.0 & 0 \\
\hline SiO 2, TESPT modified & 0 & 0 & 3.0 \\
\hline Accelerators TBBS & 1.5 & 1.5 & 1.5 \\
\hline Accelerators TMTD & 0.3 & 0.3 & 0.3 \\
\hline Sulfur, S & 2.0 & 2.0 & 2.0 \\
\hline
\end{tabular}

NR/CB: The rubber mixture contains only carbon fillers. $N R / C B / S i K B T$ : The rubber mixture contains carbon fillers and $\mathrm{SiO}_{2}$, Unmodified (SiKBT).

$N R / C B / S i B T$ : The rubber mixture contains carbon fillers and $\mathrm{SiO}_{2}$, TESPT modified (SiBT).

\subsection{Sample preparation}

Rubber and all ingredients were mixed in Baopin 8412 (China) internal mixer with the following conditions: rotor speed $35 \mathrm{rpm}$, temperature $70^{\circ} \mathrm{C}$ for 12 minutes. Mixtures were stabilized at $25{ }^{\circ} \mathrm{C}$ for 24 hours and then were vulcanized at $145{ }^{\circ} \mathrm{C}$ for 8 minutes. The cut samples were aged at $70{ }^{\circ} \mathrm{C}$ and $110^{\circ} \mathrm{C}$ for $22 \mathrm{~h}, 44 \mathrm{~h}, 88 \mathrm{~h}$. After aging, the sample was stabilized at room temperature for $24 \mathrm{~h}$ before crack fatigue testing using machine ZL3006A (China) at 300 cycles $/ \mathrm{min}$ at $140 \%$ elongation. Crack formation and propagation were observed under a digital microscope Dino-Lite at 220 magnification.

\subsection{Testing Methods}

\subsubsection{Mechanical properties}

Tensile strength, elongation at break, and residual elongation were measured using an INSTRON 5582 (America) testing machine with an extension rate of $500 \mathrm{~mm} /$ minute at room temperature (according to TCVN 4509:2006).

\subsubsection{Thermal properties}

Aging test: carried out according to TCVN 2229: 2007. The samples were aged in a Memmert oven (Germany) at $70{ }^{\circ} \mathrm{C}$ for $22 \mathrm{~h}, 44 \mathrm{~h}, 88 \mathrm{~h}$, and $110^{\circ} \mathrm{C}$ for $44 \mathrm{~h}$.

\section{Results and Discussion}

\subsection{Effect of Heat Aging and Cyclic Loading on Mechanical Properties.}

NR vulcanizates were (Formula 1, Table 1) exposed to thermal aging at $70^{\circ} \mathrm{C}$ for various periods. The mechanical properties are characterized by stressstrain curves (Fig. 1). The other results such as residual elongation as well as number of loading cycle until failure are showed in Table 2, Fig. 2, and Table 3.

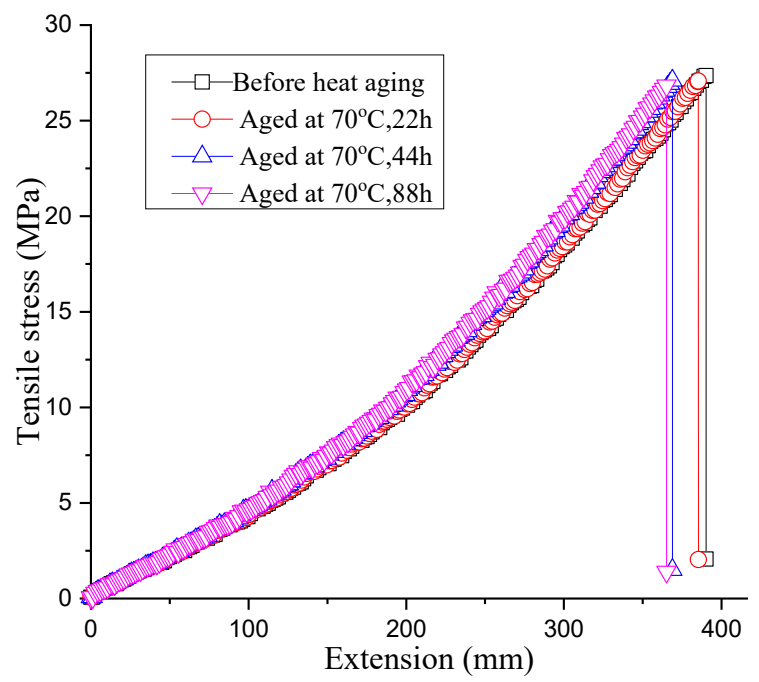

Fig. 1. Stress-Strain curves of NR vulcanizates. Before heat aging - square; Aging $70^{\circ} \mathrm{C}, 22 \mathrm{~h}$ - circle; Aging $70^{\circ} \mathrm{C}, 44 \mathrm{~h}$ - triangle up; Aging $70^{\circ} \mathrm{C}, 88 \mathrm{~h}$-triangle down 
After thermal aging, NR vulcanizates were subjected to cyclic loading of 300 cycles/minute and elongation of $140 \%$. Mechanical properties of aged vulcanizates after a certain number of loading cycles were determined. The results are shown in Fig. 2.

The results in Fig. 2 and Table 2 show that, after more than 8000 cycles, the tensile strength and elongation at the break of aged NR vulcanizate remained unchanged. One reason for this phenomenon may be the continuation after the cross-linking of the NR vulcanizers (post-cure) occurring at moderately high temperatures $\left(70{ }^{\circ} \mathrm{C}\right)$ [7-10]. However, when vulcanizates were aged at $110^{\circ} \mathrm{C}$, the post-cure cannot compensate for the structural decomposition due to heat aging therefore mechanical properties are reduced (Table 2).
Table 2. Mechanical properties of NR vulcanizates before and after aging at $70{ }^{\circ} \mathrm{C}$.

\begin{tabular}{|c|c|c|c|c|}
\hline \multirow[t]{2}{*}{ Properties } & \multicolumn{4}{|c|}{ Aging time, hours } \\
\hline & 0 & 22 & 44 & 88 \\
\hline $\begin{array}{l}\text { Tensile } \\
\text { strength, MPa }\end{array}$ & 27 & 27 & 27 & 27 \\
\hline $\begin{array}{l}\text { Elongation at } \\
\text { break, } \%\end{array}$ & 580 & 580 & 550 & 550 \\
\hline $\begin{array}{l}\text { Residual } \\
\text { elongation, \% }\end{array}$ & 28 & 28 & 26 & 26 \\
\hline $\begin{array}{l}\text { Number of } \\
\text { loading cycles } \\
\text { until failure }\end{array}$ & $\begin{array}{c}> \\
35000\end{array}$ & $\begin{array}{c}> \\
35000\end{array}$ & 35000 & 28000 \\
\hline
\end{tabular}

Table 3. Mechanical properties of NR vulcanizates before and after heat aging and cyclic loading.

(Heat aging: $110^{\circ} \mathrm{C}$ for 44 hours)

\begin{tabular}{|c|c|c|c|c|c|c|}
\hline \multirow{2}{*}{ Properties } & \multirow{2}{*}{ Unaged } & \multicolumn{5}{|c|}{ Number loading cyclic after heat aging } \\
\cline { 3 - 7 } & & 0 & 1000 & 2000 & 3000 & 4000 \\
\hline Tensile strength, MPa & 27.0 & 19.0 & 17.0 & 14.0 & 14.5 & 12.0 \\
\hline Elongation at break, \% & 580 & 250 & 220 & 225 & 210 & 190 \\
\hline Residual elongation, \% & 28 & 4.0 & 4.0 & 4.0 & 4.0 & 4.0 \\
\hline & $*$ Aged vulcanizates break after 4500 cycles of loading. \\
\hline
\end{tabular}

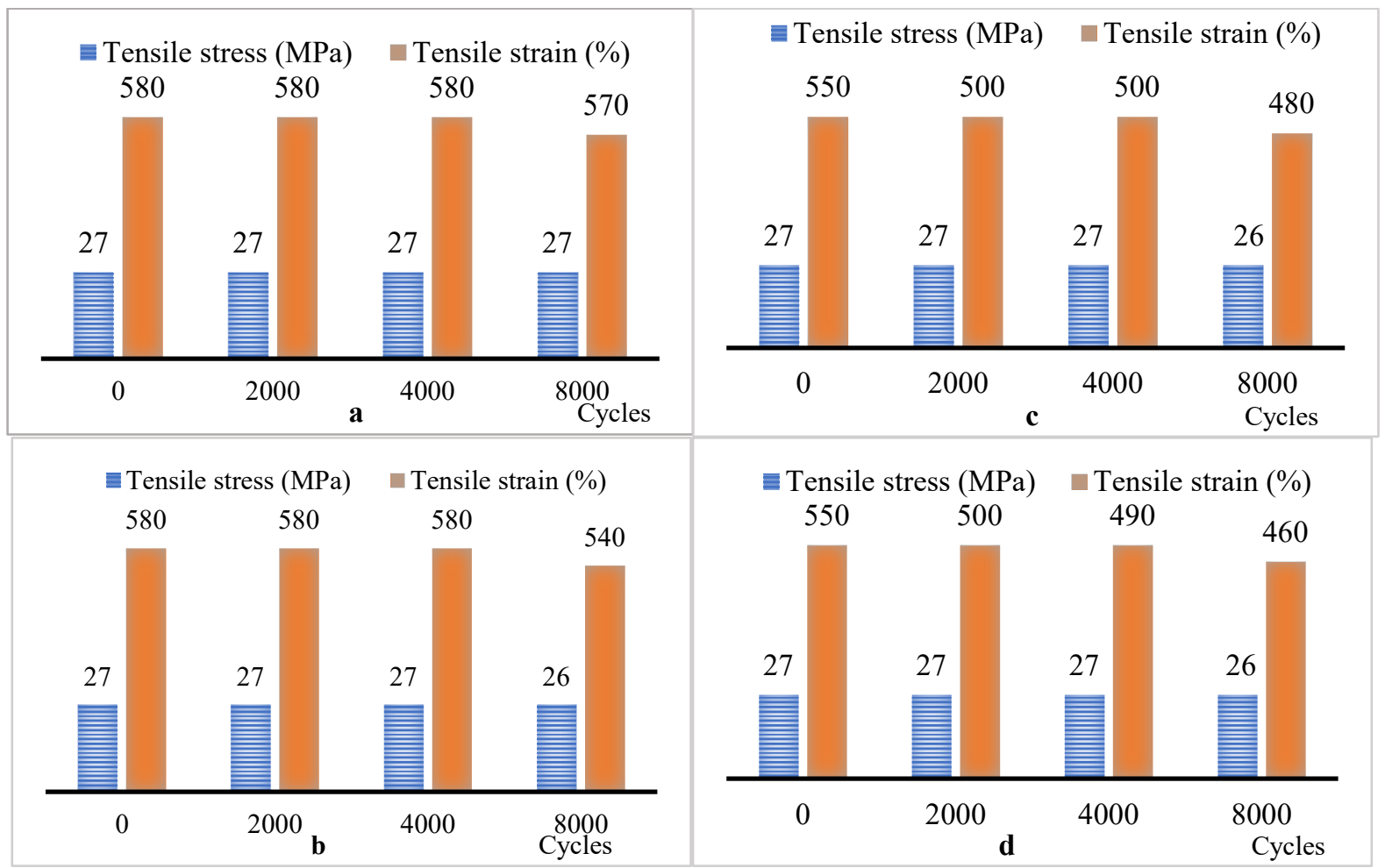

Fig. 2. Mechanical properties of aged vulcanizates after various loading cycles. (Aged at $70^{\circ} \mathrm{C}$ ). a. Unaged; b. Aged at $70^{\circ} \mathrm{C}, 22 \mathrm{~h} ; \mathrm{c}$. Aged at $70^{\circ} \mathrm{C}, 44 \mathrm{~h} ; \mathrm{d}$. Aged at $70^{\circ} \mathrm{C}$. 
Note that, in both cases (aging at $70{ }^{\circ} \mathrm{C}$ and $110^{\circ} \mathrm{C}$ ) the number of loading cycles until failure decreases significantly as the aging time increases. Such behavior of NR vulcanizates - static tensile strength is almost unchanged but dynamical durability decreases markedly after aging - may be explained by considering the stress softening effect (Mullins effect)

\subsection{Mullins Effect of NR Vulcanizates}

After the first loading cycle, the Mullins effect was revealed for NR vulcanizates both before and after heat aging (Fig. 3, Fig. 4). In subsequent load cycles, this effect has not occurred yet in stress-strain curves.

The degree of curvature in the region at the strain is about $90-100 \mathrm{~mm}$, corresponding to the amplitude of cyclic load. Mullins's effect of filled vulcanizates is attributed to some structural destruction of material while stretching [3]. This leads to the appearance of microcracks in the rubber matrix. When the sample is further stretched till failure, the crack growth is strongly prevented by strain-induced crystallization of rubber [11]. Therefore, in the case of static loads, strength enhancement by post-cure and strain induced crystallization of rubber may compensate the thermal aging destruction, thus the tensile strength of material stayed almost unchanged. In the case of cyclic loading at low elongation, and strain-induced crystallization did not occur, crack development was not prevented. Therefore, the dynamic durability of NR vulcanizates decreases. Naturally, the longer samples are exposed to heat, the more dynamic durability decreases (Table 3). The higher temperature of heat aging $\left(110^{\circ} \mathrm{C}\right)$, the lower the dynamic durability, because thermal destruction of the material is greater than the effect of post-cure.
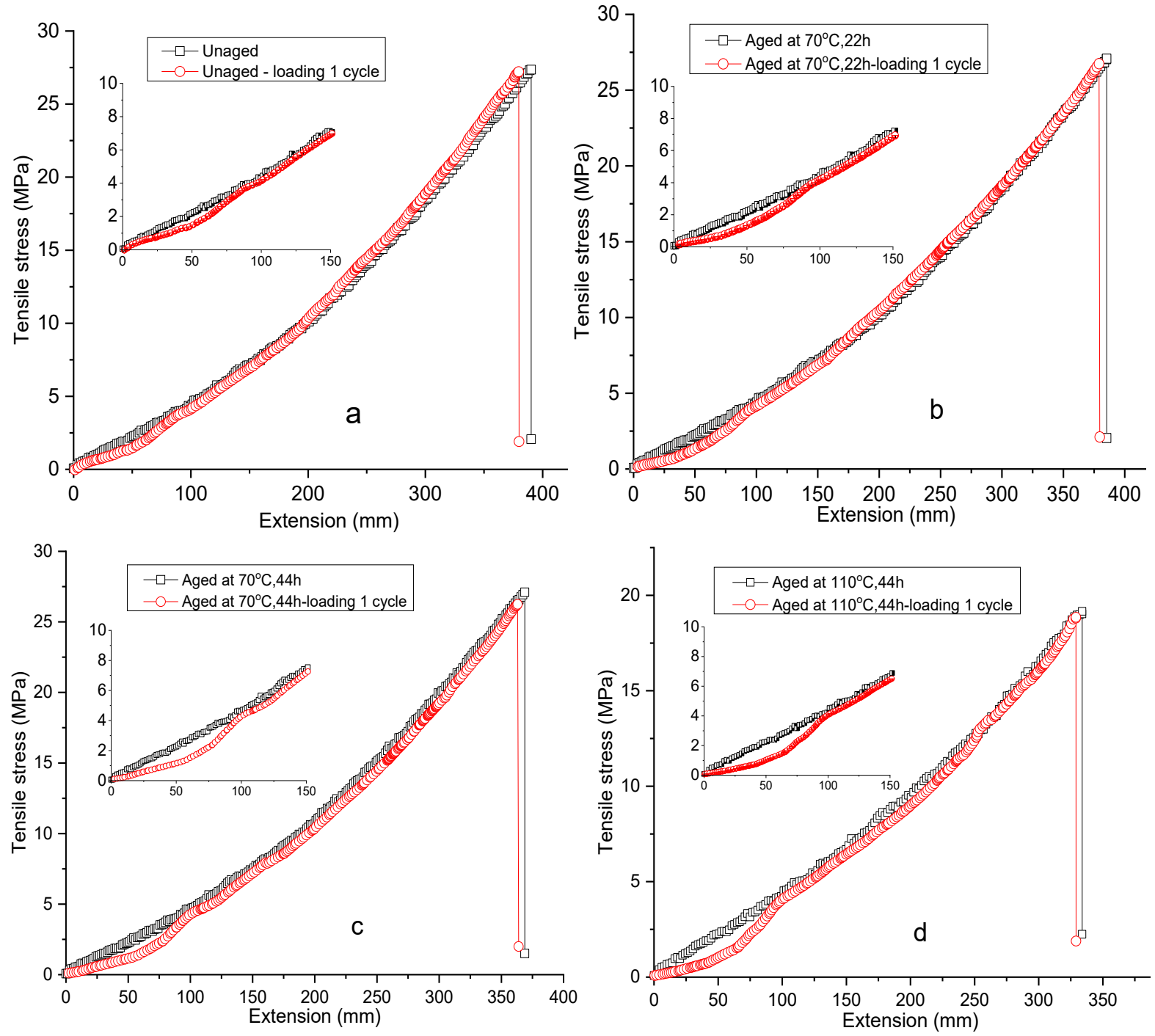

Fig. 3. Stress-strain curves of NR vulcanizates a). Unaged; b). Aged at $70^{\circ} \mathrm{C}, 22 \mathrm{~h}$; c). Aged at $\left.70^{\circ} \mathrm{C}, 44 \mathrm{~h} ; \mathrm{d}\right)$. Aged at $110^{\circ} \mathrm{C}, 44 \mathrm{~h}$ 


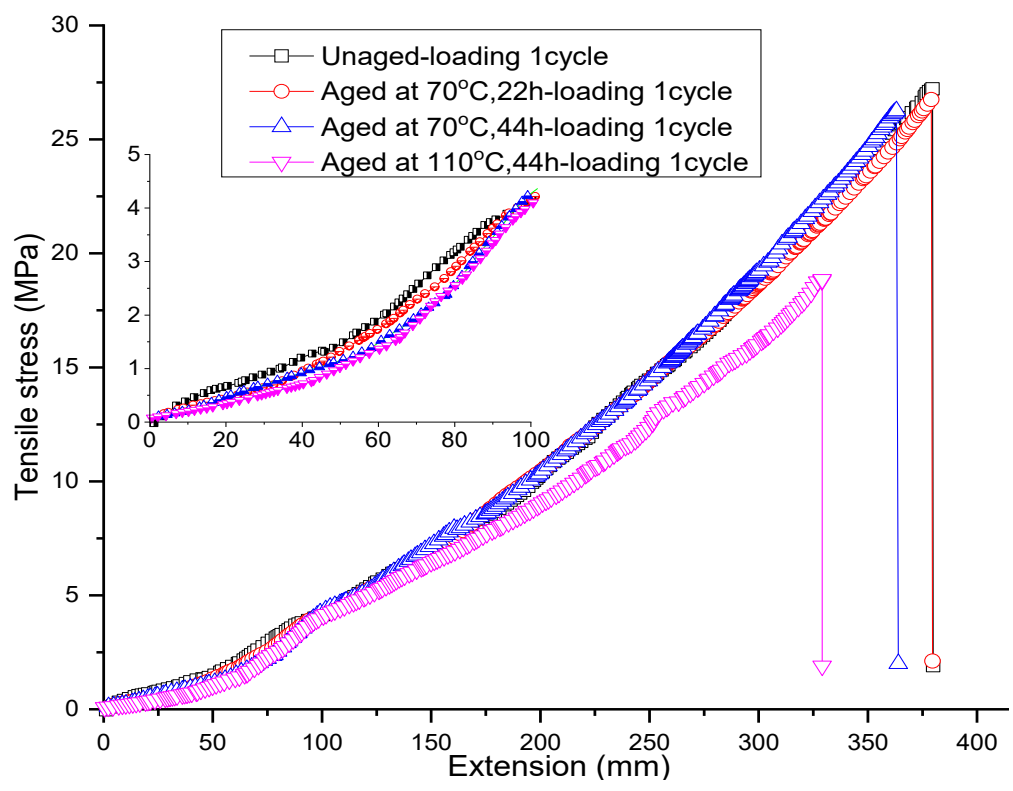

Fig. 4. Stress-strain curves of NR vulcanizates

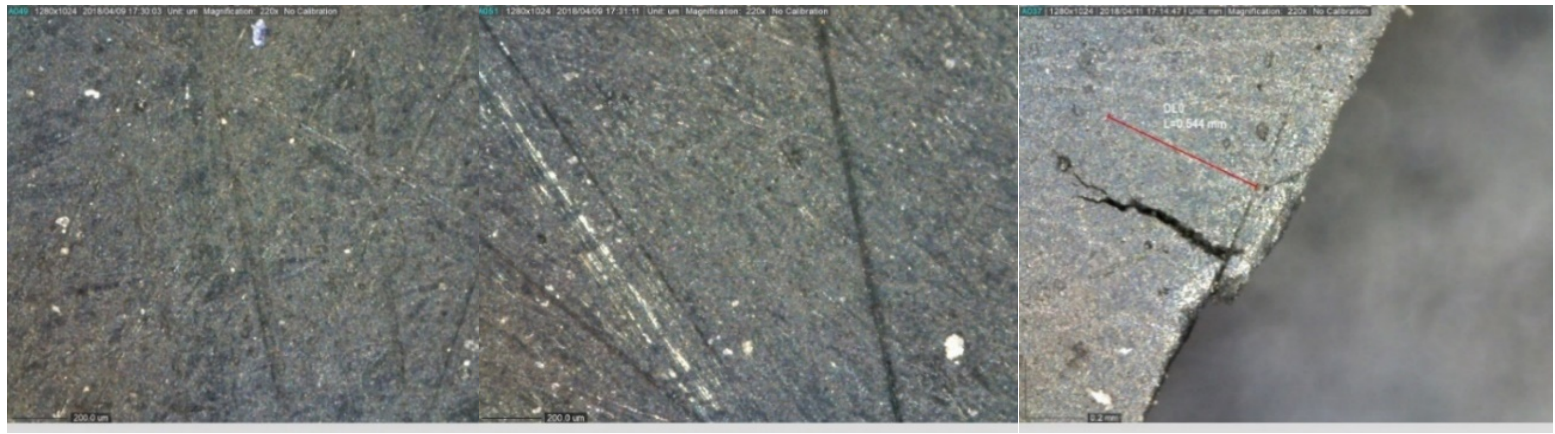

4000 cycles - no crack

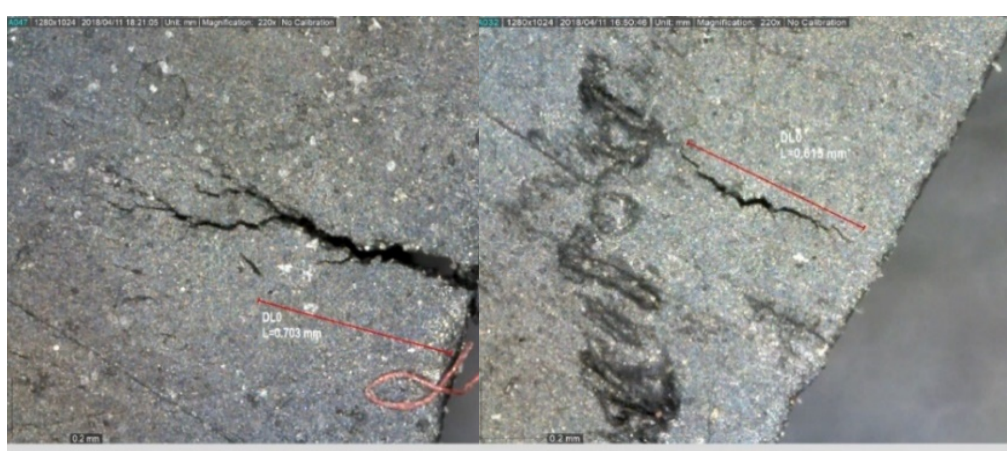

15000 cycles, crack initiated from the edge
10000 cycles crack initiated from the edge

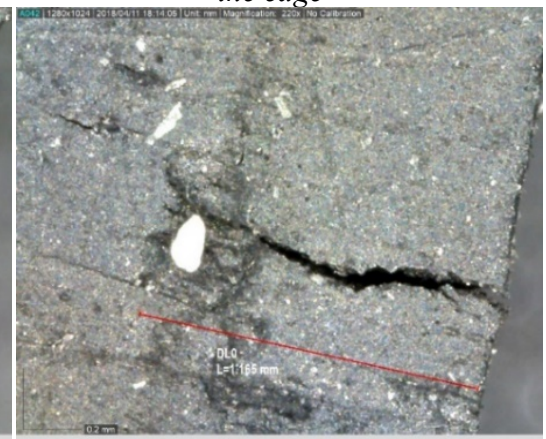

15000 cycles, crack initiated in the bulk

Fig. 5. Cracks growth on NR vulcanizate after heat aging at $70{ }^{\circ} \mathrm{C}, 96 \mathrm{~h}$, and cyclic loading.

\subsection{Effect of Filler on Crack Growth}

The Mullins effect is a 'typical' phenomenon for filled rubbers. Therefore, the influence of the two most common fillers in the rubber industry, carbon black, and silica, on crack development has been studied.

\subsubsection{Rubber mixture with carbon black}

Vulcanizates (Formula 1, Table 1) do not show any cracks until the number of load cycles reaches 10,000 . At 10,000 cycles, cracks begin to appear and have a length of about $0.5 \mathrm{~mm}$ (Fig. 5). The length of the crack is about $1.0 \mathrm{~mm}$ when the loading cycle is 15000. The crack path is not straight but has many branches in many different directions. In addition, cracks can sometimes appear both on the surface and on the edge of the sample. 


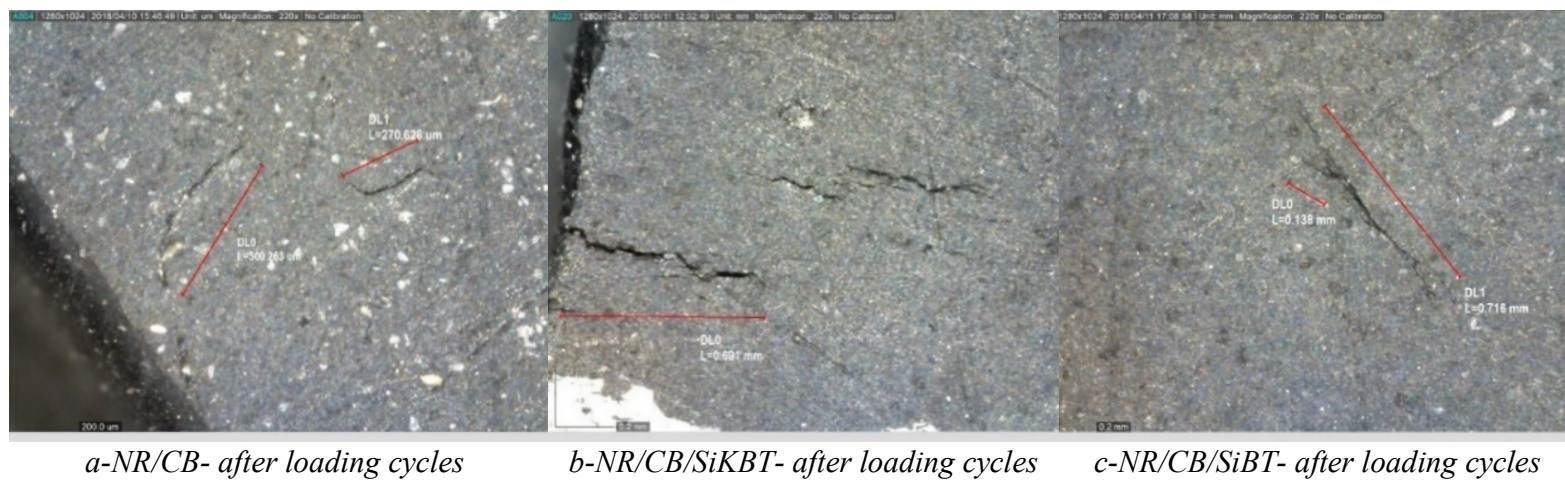

Fig. 6. Crack distribution on the surface of vulcanizates.

\subsubsection{Rubber mixtures with carbon black and silica}

Silica modified (SiBT) and unmodified (SiKBT) was added in NR mixtures with carbon black (Formula 2 and 3, Table 1). After thermal aging and cyclic loading, the number of cracks on the surface of the sample appears to be smaller, but the cracks are longer than those on the NR vulcanizate only with $\mathrm{CB}$ (Formula 1, Table 1).

From Fig. 6, one can see that the crack distribution on the vulcanized NR / CB is even more than that of NR / CB / SiBT and NR / CB / SiKBT, resulting from the poor interaction of NR and SiKBT. Therefore, the worst destructive cracks appear in the case of NR vulcanizates with unmodified silica $(\mathrm{NR} / \mathrm{CB} / \mathrm{SiKBT})$. The best resistance to crack development is observed in $\mathrm{NR} / \mathrm{CB}$ vulcanizates. $\mathrm{NR} / \mathrm{CB} / \mathrm{SiBT}$ takes an intermediate position between the two types mentioned.

\section{Conclusion}

1. Under the influence of thermal aging process at $70{ }^{\circ} \mathrm{C}$ and cyclic loading, the static tensile strength of NR vulcanizates is almost unchanged. This may be explained by that post-cure and strain-induced crystallization of material have compensated the strength reduction resulting from heat aging. In contrast, the material's fatigue strength decreases with increasing thermal aging time.

2. As the NR vulcanizates are subjected to $110^{\circ} \mathrm{C}$ aging, the thermal degradation exceeds the effect of post-cure and strain-induced crystallization of material. Consequently, both static strength and dynamic fatigue resistance decreased. In both cases (aging at $70{ }^{\circ} \mathrm{C}$ and $110^{\circ} \mathrm{C}$ ) the reduction of dynamic fatigue resistance of material may be explained, based on the Mullins effect of filled rubbers.

3. Carbon black filled NR vulcanizates have good crack growth resistance (CGR). The addition of SiBT and SiKBT can lead to a reduction in the CGR of the material. However, NR/CB/SiBT has a better CGR than that of $\mathrm{NR} / \mathrm{CB} / \mathrm{SiKBT}$.

\section{Acknowledgments}

This research is funded by the National Project $\mathrm{KC}$ 02.06/16-20. Also, the authors would like to thank the Center for Polymer Composite and Paper, HUST, for overall support.

\section{References}

[1] J.R. White and S.K. De, Rubber Technologist Handbook, Rapra Technology Ltd, Shawbury, Shrewsbury (2001).

[2] E. Mark, Burak Erman, Frederick R. Eirick, The Science and Technology of Rubber, Elsevier Academic Press, $3^{\text {rd }}$ Ed., San Diego, CA. 2005, pp.744.

[3] Julie Diani, Bruno Fayolle, Pierre Gilormini, A review on the Mullins effect, European Polymer Journal. Vol. 5 (2009) 601-612.

https://doi.org/10.1016/j.eurpolymj.2008.11.017

[4] G. Chagnon, E.Verron, G.Marckmann, L.Gornet, Development of new constitutive equation for the Mullins effect in rubber using network alteration theory, Int. J. of Solid and structure. Vol. 43 (2006) 6817-6831.

https://doi.org/10.1016/j.ijsolstr.2006.02.011

[5] Bui Chuong, Dang Viet Hung, Nguyen Thuong Giang, Using TESPT modified silica as a reinforcement filler for a blend of natural rubber-butadiene rubber, Part I: Preparation and characterization of TESPT modified silica, Vietnam J. Chem. Vol. 45 (2007) 67-71.

[6] Nguyen Trong Quang, Dang Viet Hung, Bui Chuong, Hoang Nam, Nguyen Thi Yen, Study on the effect of modified and unmodified silica on the properties of Natural Rubber vulcanizates, Vietnam Journal of Chemistry. Vol. 57 (3) (2019) 357-362. https://oi.org/10.1002/vjch.201900040

[7] Samy Merabia, Pane Sotta, Didier R. Long, Unique plastic and recovery behavior of nanofilled elastomers and thermoplastic elastomers (Payne and Mullins effects), J. of Polymer Science, Part. B: Polymer Physics. 48 (2010) 1495-1508. https://doi.org/10.1002/polb.22046

[8] Lei Yan, David A. Dillard, Robert L. West, Loren, Loren D.Lower, Glenn V. Gordon, Mullins effect recovery of nanoparticle filled polymers, J. of Polymer 
Science, Part B: Polymer Physics. 48 (2010) $2207-$ 2214.

https://doi.org/10.1002/polb.22102

[9] Hsien-Tang Chiu, Pier- AnTsai, Aging and Mechanical properties of NR/BR blends, Journal of Materials Engineering and Performance. 15 (2006) 8894.

https://doi.org/10.1361/105994906X83448
[10] Byungwoo Moon, Jongmin Lee, Soo Park, ChangSung Seok, Study on the aging behavior of Natural Rubber/ Butadiene Rubber (NR/BR) blends using a Parallel Spring Model, Polymer. 10 (2018) 658. https://doi.org/10.3390/polym10060658

[11] Present Ghosh, Rabindra Mukhopadhyay, Radek Stock, Durability prediction of NR/BR and NR/SBR blend tread compounds using tear fatigue analyzer, Testing and Measuring, (2016) 53-55. 